(C) 2017, THE AUTHORS. Published by FASS and Elsevier Inc. on behalf of the American Dairy Science Association ${ }^{\circledR}$.

This is an open access article under the CC BY-NC-ND license (http://creativecommons.org/licenses/by-nc-nd/3.0/).

\title{
Effect of pre- and postpartum supplementation with lipid-encapsulated conjugated linoleic acid on reproductive performance and the growth hormone-insulin-like growth factor-I axis in multiparous high-producing dairy cows
}

\author{
Z. Csillik, ${ }^{* 1}$ V. Faigl,† M. Keresztes, † E. Galamb,‡ H. M. Hammon,§ A. Tröscher, ${ }^{*}$ H. Fébel,\# M. Kulcsár,† \\ F. Husvéth, $\ddagger$ Gy. Huszenicza, $†$ and W. R. Butlerll \\ *BASF SE, 68623 Lampertheim, Germany \\ †University of Veterinary Medicine, István u. 2, 1078 Budapest, Hungary \\ ¥Georgikon Faculty, University of Pannonia, Deák F. u. 16, 8360 Keszthely, Hungary \\ §Research Unit Nutritional Physiology “Oskar Kellner," Leibniz Institute for Farm Animal Biology, Wilhelm-Stahl-Allee 2, 18196 Dummerstorf, \\ Germany \\ \#Nutrition and Meat Science, National Agricultural Research and Innovation Centre, Research Institute for Animal Breeding, Gesztenyés út 1, \\ 2053 Herceghalom, Hungary \\ IIDepartment of Animal Science, Cornell University, Ithaca, NY 14853-6401
}

\section{ABSTRACT}

The objective of the study was to evaluate the effect of prepartum and postpartum (PP) supplementation with 2 isomers of conjugated linoleic acid (CLA) on reproductive parameters and some related metabolic factors in dairy cows. High-producing, multiparous Holstein Friesian cows $(\mathrm{n}=60)$ were allotted to 3 treatment groups: the CLA1 group $(\mathrm{n}=20)$ was supplemented with $70 \mathrm{~g}$ of lipid-encapsulated CLA providing $7 \mathrm{~g}$ each of cis-9,trans-11 and trans-10,cis-12 CLA from d 21 (d 21) before expected calving until d 7 after artificial insemination (AI), that is, until 77 to $91 \mathrm{~d}$ PP; the CLA2 group $(\mathrm{n}=20)$ was supplemented with the same amount of CLA beginning at calving until d 7 after AI; and the control group $(\mathrm{n}=20)$ received an isocaloric, isonitrogenous, and isolipidic diet. Blood samples were taken weekly to measure glucose, insulin, insulin-like growth factor-I (IGF-I), and leptin. Liver biopsy was performed in 10 cows per group for growth hormone receptor $1 \mathrm{~A}$ and $I G F-I$ mRNA analyses. At d 49 to $63 \mathrm{PP}$, ovulation was synchronized with the Pre-Synch protocol followed by fixed-time AI. Milk progesterone was monitored from calving until d 35 post-AI. Cows returning to estrus following AI were inseminated. Supplementation with CLA before calving improved the recovery of plasma leptin levels in the early PP period (from the day of calving until wk 3 PP; treatment effect). Later PP (wk 5), plasma IGF-I, and leptin remained significantly higher in both CLA1 and CLA2 groups compared with control, although

Received October 7, 2016.

Accepted March 4, 2017.

${ }^{1}$ Corresponding author: zoltan.csillik@basf.com or zoltan@csillik.hu hepatocellular IGF-I mRNA was not different among groups. Plasma IGF-I levels remained higher in both CLA-treated groups on the day of AI. Growth hormone receptor 1A mRNA levels in hepatic tissue decreased in all groups, reaching a nadir in the first week PP. Days to first PP ovulation did not differ between groups; however, both supplemented groups conceived earlier compared with control (d $97 \pm 19$, d $97 \pm 23$, and d $113 \pm 30$ for CLA1, CLA2, and control, respectively). Plasma progesterone concentration was higher in both supplemented groups on d 2 to 5 following the synchronized ovulation than in controls. We concluded that CLA supplementation around calving alters PP metabolic signals as reflected by higher plasma leptin and IGF-I levels. Conjugated linoleic acid stimulated early luteal function and reduced the PP interval to conception.

Key words: conjugated linoleic acid, insulin, insulinlike growth factor, postovulatory progesterone raise, conception

\section{INTRODUCTION}

Reproductive performance in dairy cows has declined over the past decades in association with remarkable increases in milk yields both in confinement and pasture-based systems (Lucy, 2001; Wiltbank et al., 2006; Chagas et al., 2007). Various authors have attributed this decline in fertility to negative energy balance (NEB), metabolic disorders, insulin resistance, changes in the uncoupling/recoupling of the growth hormone (GH)-IGF-I axis, uncoupling/recoupling in fat metabolism, and low level inflammatory processes (Butler and Smith, 1989; Beam and Butler, 1999; O'Callaghan and Boland, 1999; Rukkwamsuk et 
al., 1999; Webb et al., 1999; Butler, 2000; Jorritsma et al., 2000; Butler, 2001). Inclusion of different fat sources in the lactating dairy cow diet may influence metabolic parameters, reproductive performance, and health status via alleviating NEB, improving follicular development and functions, and improving corpus luteum (CL) function (Mattos et al., 2000; Robinson et al., 2002; Butler, 2003; Butler et al., 2003, 2006; Castañeda-Gutiérrez et al., 2007; de Veth et al., 2009; May et al., 2011). Among PUFA, particular attention has been given to 2 specific CLA isomers (cis9,trans-11 CLA and trans-10,cis-12 CLA) because of their biological effects on metabolism and fertility (Bernal-Santos et al., 2003; Castañeda-Gutiérrez et al., 2005, 2007; Hutchinson et al., 2011). Fat mobilization and its detrimental consequences were reduced in CLAsupplemented cows, which resulted in improved energy status and body condition (Hutchinson et al., 2011). Many studies suggest a tendency for CLA to decrease the time to pregnancy and to increase conception rate following insemination (Bernal-Santos et al., 2003; Castañeda-Gutiérrez et al., 2005; de Veth et al., 2009). One possible reason for the observed higher conception rate may be decreased early embryo losses. In previous studies, authors proposed that dietary PUFA as well as CLA isomers can reduce endometrial $\mathrm{PGF}_{2 \alpha}$ synthesis and thus decrease embryo mortality (Mattos et al., 2000; Castañeda-Gutiérrez et al., 2007). An increased postovulatory $\mathrm{P} 4$ rise could also contribute to optimum uterine environment for the elongation of the embryo, which will produce higher amount of interferon $\tau$ inhibiting $\mathrm{PGF}_{2 \alpha}$ release from the endometrium. CastañedaGutiérrez et al. (2007) found increased postovulatory $\mathrm{P} 4$ rise between d 6 and 8 following ovulation in cows supplemented with 2 different CLA preparations. Those authors also found a direct correlation between the amount of trans-10,cis-12 CLA-supplemented and higher plasma IGF-I levels. The results suggested that the beneficial effect of CLA may be attributed to elevated IGF-I, which promotes follicular and luteal cell proliferation, induced P4 synthesis (Perks et al., 1999), and increased LH binding by bovine thecal cells (Stewart et al., 1995). Increased IGF-I plays a critical role during maturation of $\mathrm{PP}$ dominant follicles and improves ovarian steroidogenesis (Butler et al., 2004).

All of the above studies started CLA administration in the postpartum (PP) period. The hypothesis of our study was that beneficial effects of CLA would be expressed more if supplementation started before calving, allowing for an accumulation of CLA preceding the large metabolic challenges. Beneficial effects were defined as (1) higher plasma IGF-I levels in treated groups (specific for earlier recoupling of the GH-IGF-I axis), and (2) higher postovulatory progesterone (P4) rise, ensuring a better intrauterine environment for embryo development (Inskeep, 2004).

Moreover, we determined the proportion of animals conceiving from timed AI following the voluntary waiting period and the period from calving to conception. To have an insight on the possible mechanisms behind CLA induced IGF-I elevation, we also assessed the growth hormone receptor $1 \mathrm{~A}(G H R 1 A)$ and $I G F-I$ mRNA expression in the liver.

\section{MATERIALS AND METHODS}

\section{Animal Housing and Feeding}

The study was approved by the local animal health services (Tolna County, Hungary, authorization: DK$38 / 2 / 2007$ ) and was conducted in a commercial dairy farm (Milkmen Ltd., Paks, Hungary) having approximately 800 cows with a mean milk yield of $12,000 \mathrm{~kg}$ per lactation. Cows were kept and fed in a free-stall housing system. Multiparous, high-producing, clinically healthy Holstein Friesian cows $(\mathrm{n}=60)$ were allotted to 3 treatment groups and blocked according to age, parity, BCS, and milk production during the first $100 \mathrm{~d}$ of the preceding lactation. From the beginning until the end of treatment the study, animals were kept in small group pens according to their assignment. Groups were filled up continuously through the experimental period and animals were removed gradually from the groups as they reached the end of treatment. The following diseases and pathophysiological conditions were used as exclusion criteria: early parturition, twin parturition, dystocia, retained fetal membranes, puerperal metritis, mastitis, and displaced abomasum.

The experimental feed was offered from d 21 before the anticipated calving until d 77 to $91 \mathrm{PP}$, that is, 7 $\mathrm{d}$ following the AI (Figure 1). The diets were balanced according to the guidelines of NRC (2001). The ingredient and nutrient composition is summarized in Table 1. A separate article discusses milk production data, liver lipid content, and metabolic findings of the same experiment (Galamb et al., 2016). The daily TMR ration for CLA1 group $(\mathrm{n}=20)$ was supplemented with $70 \mathrm{~g}$ of Lutrell Pure (BASF SE, Ludwigshafen, Germany) from $21 \mathrm{~d}$ before calving until d 7 after AI. The CLA2 group $(\mathrm{n}=20)$ was supplemented with $70 \mathrm{~g}$ of Lutrell Pure from calving until d 7 after AI. Prepared in ground corn as a pre-mix, CLA supplementation provided $7 \mathrm{~g}$ of each CLA isomers (cis-9,trans-11 CLA and trans-10, cis-12 CLA) per cow in both supplemented groups. From d 7 after AI, both CLA-supplemented groups were fed the same diet as controls. The diet for the control group $(\mathrm{n}=20)$ was supplemented with $55 \mathrm{~g}$ of fatty acids (Opitmus, Provimi Hungary, Zichyújfalu, 


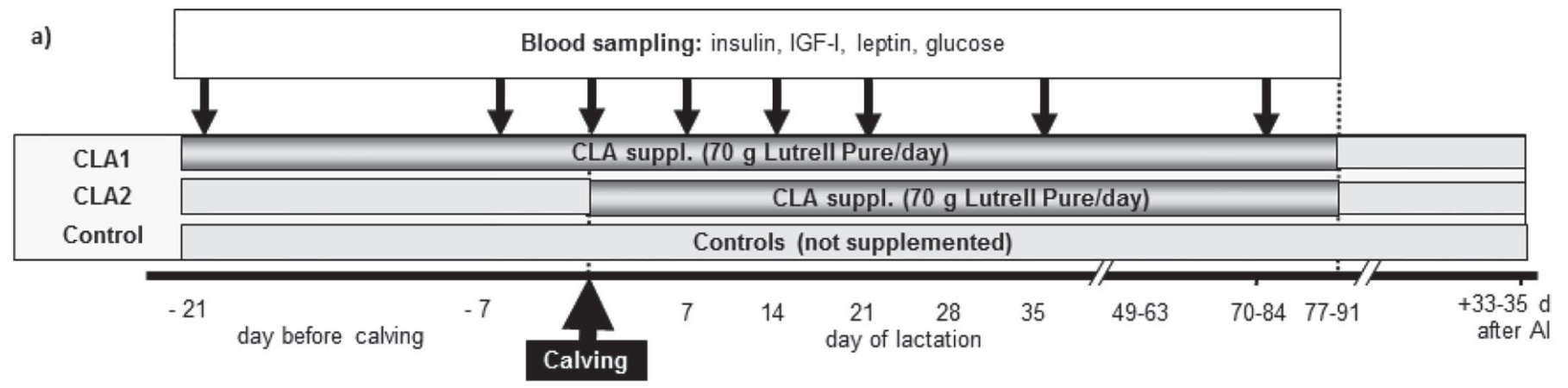

b)
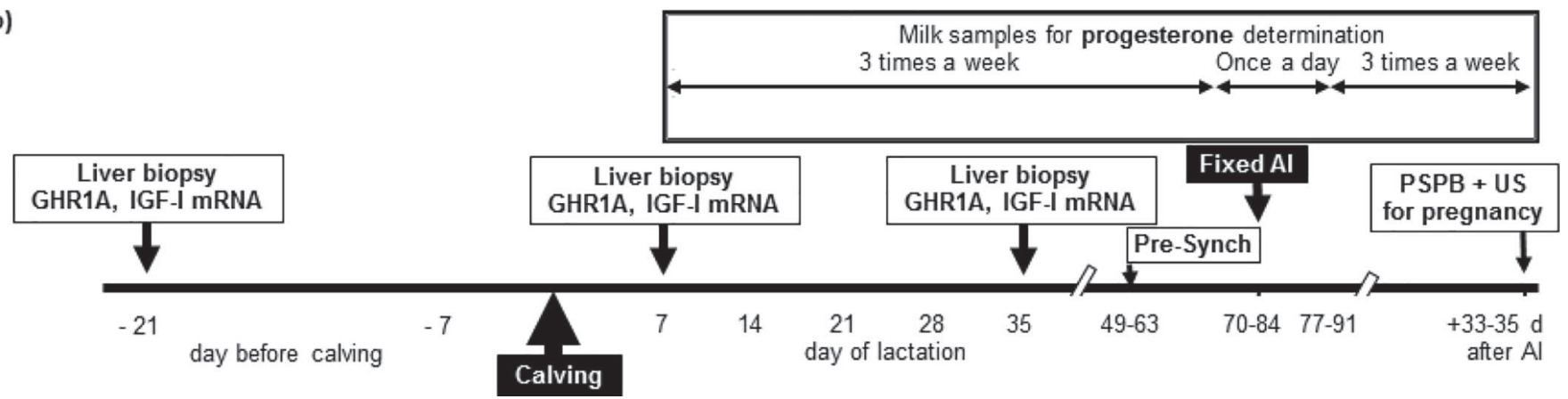

Figure 1. Experimental design. (a) Feeding supplementation relative to day of calving and timing of blood sample collection. (b) Timing of liver biopsy sampling, the synchronization protocol, and fixed-time AI. Following-up of ovarian activity by progesterone profile, and pregnancy check at d 33 to 35 following AI. US = rectal ultrasonography; GHR1A= growth hormone receptor 1A; CLA1 = cows supplemented (suppl.) from 3 wk before the expected day of parturition until $7 \mathrm{~d}$ following timed AI; CLA2 = cows supplemented from parturition until $7 \mathrm{~d}$ following timed AI. Lutrell Pure (BASF SE, Ludwigshafen, Germany); PSPB = pregnancy-specific protein B.

Hungary) to become isocaloric, isonitrogenous, and isolipidic with the CLA-supplemented diets. Cows were fed once daily before parturition and twice daily PP. Animals were milked 4 times a day.

\section{Blood Sampling and Liver Biopsy}

Blood samples were collected from $21 \mathrm{~d}$ before the anticipated calving until d 35 after fixed-time AI including wk 3 and 1 before calving; on the day of parturition; at wk 1, 2, 3, and $5 \mathrm{PP}$; on the day of $\mathrm{AI}$; and $35 \mathrm{~d}$ later (Figure 1). Blood was collected before the morning feeding into tubes containing $\mathrm{NaF}$ (for blood glucose analysis) and K-EDTA (for assaying plasma insulin, IGF-I, and leptin concentrations). The samples were cooled and centrifuged within $60 \mathrm{~min}$; plasma was harvested immediately and aliquoted into 5 equal parts for the different assays and stored at $-60^{\circ} \mathrm{C}$.

A subset of 10 cows from each of the 3 treatment groups was selected randomly for repeated percutaneous liver biopsies at the beginning of the study (3 wk before calving), in the first week and in the fifth week after calving. Liver biopsy was performed in the 11th intercostal space slightly above an imaginary line from the tuber coxae to the point of the elbow. The biopsy site was surgically prepared and injected with a local anesthetic $(10 \mathrm{~mL}$ of procain-hydrochloride, Minocain, Kon-Pharma GmbH, Hannover, Germany). After 10 min, a stab incision was made with a pointed scalpel $(0.5 \mathrm{~cm})$. A 7 -gauge, 17 -cm liver biopsy instrument was inserted through the incision and the intercostal muscles and into the liver. Approximately 700 to 800 mg of hepatic tissue was collected at each biopsy and stored in liquid nitrogen until further analysis. The incision was sutured and sprayed with topical antiseptic.

\section{Ovarian Synchronization and Reproductive Parameters}

The synchronization protocol used is shown in Figure 2. The modified version of Pre-Synch protocol proposed by Moreira et al. (2001) for synchronization of ovarian cyclicity was initiated between d 49 and 63 after calving by administering the first $\mathrm{PGF}_{2 \alpha}$ dose $(25 \mathrm{mg}$ of dinoprost, Enzaprost $\mathrm{T}$ inj., Ceva, Libourne, France). It was followed by $\mathrm{GnRH}$ treatment $(0.01 \mathrm{mg}$ of buserelin, Receptal inj., Intervet International BV, AN-Boxmeer, the Netherlands) $12 \mathrm{~d}$ later, and by a second $\mathrm{PGF}_{2 \alpha}$ 


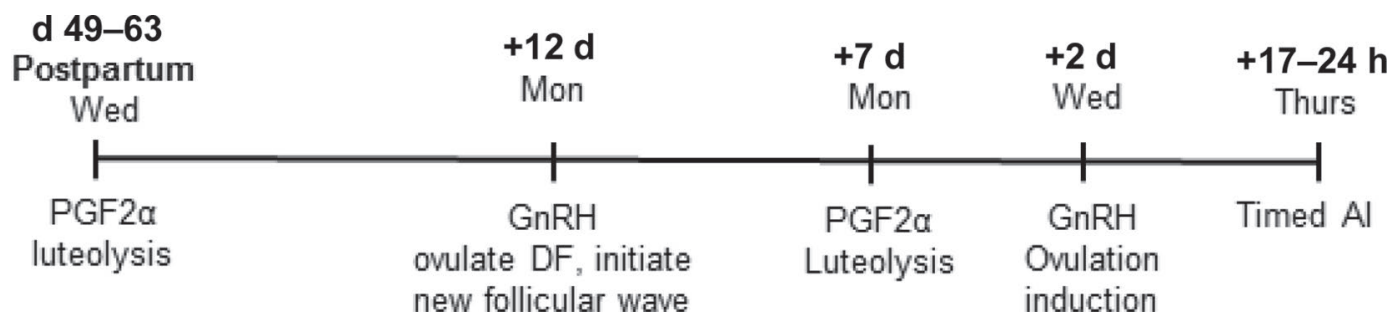

Figure 2. Modified version of Pre-Synch protocol. DF = dominant follicle; Mon = Monday; Wed = Wednesday; Thurs = Thursday.

injection $7 \mathrm{~d}$ afterward. The second $\mathrm{GnRH}$ was administered $48 \mathrm{~h}$ after the second $\mathrm{PGF}_{2 \alpha}$ treatment and cows were artificially inseminated (fixed-time AI) with frozen-thawed semen 17 to $24 \mathrm{~h}$ after GnRH (Table 2 ). Practical implementation of the synchronization protocol was adapted to the management practice of

Table 1. Ingredient composition and nutrient content of diets $(\mathrm{g} / \mathrm{kg}$ of DM)

\begin{tabular}{lcc}
\hline Item & Prepartum $^{1}$ & Postpartum $^{2}$ \\
\hline Ingredient & & \\
Corn silage & 273.5 & 272.2 \\
Brewers grain, wet & 58.0 & 69.6 \\
Alfalfa haylage & & 75.8 \\
Sudan grass silage & 127.0 & 51.1 \\
Grass silage & 301.0 & \\
Alfalfa hay & & 127.6 \\
Corn grain, ground & 108.0 & 198.2 \\
Wheat grain, ground & 43.7 & 37.0 \\
Sunflower meal & 43.7 & 22.4 \\
Rapeseed meal & & 37.3 \\
Soybean meal & 45.1 & 36.6 \\
Close-up concentrate & & \\
Lactating concentrate & & 72.2 \\
Energy and nutrients & & \\
NE (MJ/kg of DM) & 6.95 & 6.95 \\
CP & 152.0 & 172.0 \\
Ether extract & 46.0 & 61.0 \\
NDF & 384.0 & 317.0 \\
ADF & 223.0 & 189.0 \\
RUP & 47.0 & 61.3 \\
Ca & 5.7 & 7.9 \\
P & 4.7 & 4.6 \\
\hline
\end{tabular}

${ }^{1}$ From 3 wk before calving until calving. CLA1 = CLA supplementation from 3 wk before expected calving; CLA2 = CLA supplementation from calving; control = without CLA supplementation.

${ }^{2}$ From calving until 11 wk of lactation.

${ }^{3}$ Composition: $500 \mathrm{~g} / \mathrm{kg}$ of processed soybean meal (RUP $\left.=72 \%\right) ; 235$ $\mathrm{g} / \mathrm{kg}$ of dry cow mineral and vitamin premix $(14.9 \mathrm{~g} / \mathrm{kg}$ of $\mathrm{Na} ; 22.8 \mathrm{~g} /$ $\mathrm{kg}$ of Cl; $27.7 \mathrm{~g} / \mathrm{kg}$ of Ca; $20.6 \mathrm{~g} / \mathrm{kg}$ of P; $980 \mathrm{mg} / \mathrm{kg}$ of Fe; $1,170 \mathrm{mg} /$ $\mathrm{kg}$ of Zn; $1,560 \mathrm{mg} / \mathrm{kg}$ of Mn; $430 \mathrm{mg} / \mathrm{kg}$ of Cu; $24.2 \mathrm{mg} / \mathrm{kg}$ of I; 9.8 $\mathrm{mg} / \mathrm{kg}$ of Co; $11.7 \mathrm{mg} / \mathrm{kg}$ of Se; $215,000 \mathrm{IU} / \mathrm{kg}$ of vitamin A; 64,900 $\mathrm{IU} / \mathrm{kg}$ of vitamin D; $3,200 \mathrm{mg} / \mathrm{kg}$ of vitamin E; $41.6 \mathrm{~g} / \mathrm{kg}$ of choline chloride; and $25 \mathrm{mg} / \mathrm{kg}$ of $\beta$-carotene).

${ }^{4}$ Composition: $684.3 \mathrm{~g} / \mathrm{kg}$ of processed soybean meal (RUP $=72 \%$ ); $260.5 \mathrm{~g} / \mathrm{kg}$ of lactating cow mineral and vitamin premix $(23.7 \mathrm{~g} / \mathrm{kg}$ of $\mathrm{Na} ; 12.5 \mathrm{~g} / \mathrm{kg}$ of Cl; $37.3 \mathrm{~g} / \mathrm{kg}$ of Ca; $13.9 \mathrm{~g} / \mathrm{kg}$ of P; $9.8 \mathrm{~g} / \mathrm{kg}$ of Mg; $260 \mathrm{mg} / \mathrm{kg}$ of Fe; $1,040 \mathrm{mg} / \mathrm{kg}$ of Zn; $730 \mathrm{mg} / \mathrm{kg}$ of Mn; $210 \mathrm{mg} / \mathrm{kg}$ of $\mathrm{Cu} ; 11.6 \mathrm{mg} / \mathrm{kg}$ of I; $2.1 \mathrm{mg} / \mathrm{kg}$ of Co; $5.3 \mathrm{mg} / \mathrm{kg}$ of Se; $126,600 \mathrm{IU} / \mathrm{kg}$ of vitamin A; $25,320 \mathrm{IU} / \mathrm{kg}$ of vitamin D; $528 \mathrm{mg} / \mathrm{kg}$ of vitamin E; 13.1 $\mathrm{g} / \mathrm{kg}$ of choline chloride; and $50 \mathrm{mg} / \mathrm{kg}$ of $\beta$-carotene). the farm. Hormones were administered on Mondays and Wednesdays (see Figure 2) and fixed-time AI took place on Thursdays. Animals were handled in batches with an interval of $2 \mathrm{wk}$, meaning that cows reaching 49 to $63 \mathrm{~d} \mathrm{PP}$ received their first $\mathrm{PGF}_{2 \alpha}$ injection on the same calendar day. To avoid bias arising from the difference in the day of AI, we homogeneously distributed dams between the 3 treatment groups according to date of parturition.

Estrus was assessed by visual observation for approximately 60 min 3 times a day (early morning at sunrise, late morning before second feeding and late evening around $2100 \mathrm{~h}$ ). All detected heats were documented before and during the synchronization protocol, but animals were not inseminated before the day of the fixed-time AI. Fixed-time AI was performed on the assigned day independent of the signs of estrus unless the cow showed endometritis. Pregnancy was confirmed with rectal ultrasonography performed between d 33 to 35 after the timed AI and by the level of plasma pregnancy-specific protein B (PSPB) on the same day. Rectal examination was performed again between d 60 to 67 to follow up pregnancy status.

Cows that did not conceive from the initial timed AI and returned to estrus were re-inseminated upon next estrus.

Ovarian activity was monitored by individual milk P4 profiles from milk samples collected 3 times weekly from d 7 after calving until the day of the second $\mathrm{PGF}_{2 \alpha}$ administration of the modified Pre-Synch protocol. From then on, milk samples were collected daily for 2 wk, and then 3 times weekly until $35 \mathrm{~d}$ following the fixed-time AI (Figure 1).

Late embryo mortality was suspected when no embryo was visualized at the d 33 to 35 ultrasonography, but P4 level was elevated after d 16 or high PSPB level was detected on d 35 (or both).

\section{Laboratory Procedures}

Glucose Level and Metabolic Hormones. Glucose was analyzed by a commercial kit (Diagnosticum Ltd., Budapest, Hungary) with a sensitivity of 0.019 
Table 2. Reproductive responses $( \pm \mathrm{SD})$ of cows supplemented with CLA pre- and postpartum (CLA1), postpartum (PP; CLA2), and nonsupplemented (control)

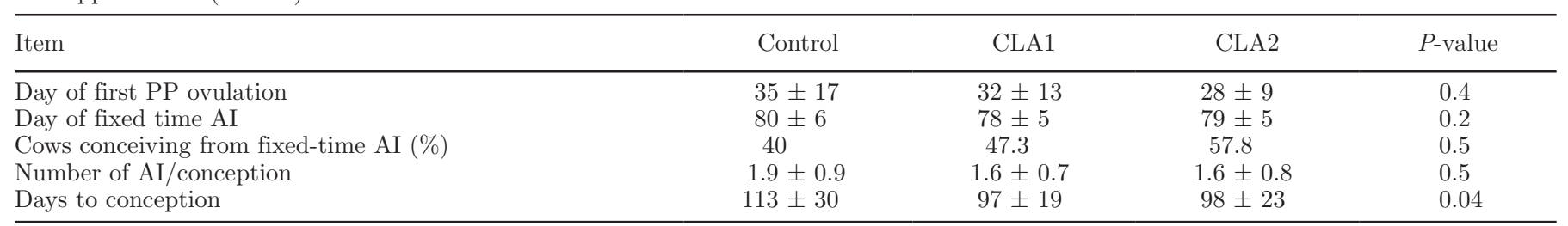

$\mathrm{mmol} / \mathrm{L}$ and intra- and interassay coefficients of variation of 0.75 and $1.47 \%$, respectively.

All endocrine assays used in this study were previously validated for bovine plasma: the binding pattern of serially diluted plasma samples (with known high quantity of the hormone analyzed) was parallel to standard curves; the recovery rates of added known quantity of hormones to standard bovine plasma samples varied between 95 and 106\%. The lower limit of detection (sensitivity) was determined with a blank sample that did not contain the analyte of interest and a spiked sample containing a low concentration of the analyte. The intra- and interassay precision based on the coefficient of variation (\%) of each assay was determined using triplicates of 3 different levels (low, intermediate, and high) of quality control samples of known quantity of the analyzed hormone. The results were accepted only if the measured concentrations of quality control samples were within the $95 \%$ confidence limit.

Insulin-like growth factor I blood serum concentration was measured with a ${ }^{125}$ I-labeled IGF-1-RIA coated tube method (Cisbio Bioassays, Codolet, France) developed for human samples, which was adapted and validated for bovine samples as described by Balogh et al. (2012). Following extraction of IGF-I with an ethanolic $\mathrm{HCl}$ solution and neutralization, the extract was incubated with assay reagents at $4^{\circ} \mathrm{C}$ for $12 \mathrm{~h}$. Further analysis was performed according to the manufacturer's description. Sensitivity was $0.99 \mathrm{nmol} / \mathrm{L}$; intra- and interassay coefficients of variation were 3.5 to $7.2 \%$ and $\leq 7.3 \%$, respectively.

Insulin concentration was measured as free insulin with a commercial ${ }^{125} \mathrm{I}$-BI-Insulin immunoradiometric assay (BI-INS-IRMA kit, Cisbio Bioassays) developed for human samples and validated for bovine plasma (Kerestes et al., 2009). Sensitivity was $0.35 \mu \mathrm{IU} / \mathrm{mL}$. Intra- and interassay coefficients of variation were between 3.61 to $9.02 \%$ and $\leq 8.5 \%$, respectively.

Leptin was measured by RIA using a Multi-Species Leptin ${ }^{125}$ I RIA kit (Millipore Co., Billerica, MA) recommended for leptin analysis in cows and validated for bovine plasma as described above. Sensitivity was $1.16 \mathrm{ng} / \mathrm{mL}$; intra- and interassay assay coefficients of variation were between 5.57 to $10.44 \%$ and $\leq 9.5 \%$, respectively.

PSPB and Progesterone Measurement. The PSPB collected between d 33 to 35 after the timed AI was measured by a BioPRYN assay (BioTracking LLC, Moscow, ID) providing a yes or no pregnancy result. If the optical density (OD) reading for a sample exceeds a cutoff OD, the animal is called pregnant. The cut-off value was calculated from the $\mathrm{OD}$ values of triplicate test wells for 2 PSPB standards equivalent to $0.024 \mathrm{ng}$ of PSPB in the test well.

Milk samples for $\mathrm{P} 4$ were collected in vials containing sodium azide and kept at $4^{\circ} \mathrm{C}$ until analysis. Progesterone content of skim milk was determined with a semi-automated immunoassay method (using the P4 kit of AXSYM Abbott Diagnostic Division) within 14 d after collection. Threshold P4 level for active CL was determined as $1.5 \mathrm{nmol} / \mathrm{L}$. The interassay coefficient of variation was 5.28 to $8.68 \%, 2.81$ to $5.53 \%$, and 4.65 to $6.25 \%$ for the manufacturer's bovine low, medium, and high controls, respectively. The intraassay coefficient of variation was $<10 \%$. Sensitivity was $0.43 \pm 0.036$ $\mathrm{nmol} / \mathrm{L}$ (mean $\pm \mathrm{SEM})$.

Real-Time PCR Methods for GHR1A and IGF-I mRNA Analyses. Total RNA was isolated from liver samples, transcribed into cDNA, and purified (Hammon et al., 2009). Specific primer sequences were used as described in previous studies (GHR1A according to Kendall et al., 2003; IGF- $I$ according to Pfaffl et al., 2002). Quantification of mRNA concentrations relative to reference genes in liver tissue was done by real-time reverse-transcription PCR (LightCycler, Roche Applied Science, Mannheim, Germany) using SYBR Green I as fluorescent dye. The GAPDH and phosphoglycerate kinase were used as reference genes (Ref) because they were not affected by CLA and time. Each product was verified by detection of melting temperatures. Additionally, gel electrophoresis of the PCR product demonstrated only one single band of the expected size. Products were verified by sequencing using an ABI Sequencing kit (ABI Big Dye Terminator, Applied Biosystems, Darmstadt, Germany) and an ABI 310 Genetic Analyzer (Applied Biosystems). 
Values of the crossing point (quantification cycle; Cq) were corrected for different runs by an internal standard $(\Delta \mathrm{Cq})$. In addition, $\Delta \mathrm{Cq}_{\text {Ref }}$ was used to normalize target genes as indicated by $\Delta \Delta \mathrm{CP}=\Delta \mathrm{Cq}_{\text {target }}-\Delta \mathrm{Cq}$ Ref (Hammon et al., 2009). Efficiency of PCR was >1.8 and inter- and intra-assay coefficients of variation for reverse-transcription PCR of target and reference genes were $<1 \%$ (Hammon et al., 2009).

\section{Statistical Analysis}

Sample size for primary endpoints was pre-determined based on the publication of Castañeda-Gutiérrez et al. (2007) who investigated the effect of CLA supplementation topdressed on the feed once daily during the interval from $20 \pm 1$ DIM to $56 \pm 1$ DIM. Their study involved 15 cows per treatment group and was able to detect significant effect of a similar supplementation $(7.1 \mathrm{~g} / \mathrm{d}$ of each CLA isomers) on IGF-I levels during the dietary treatment period versus control (Ca salts of tallow). The same study confirmed a trend for cows receiving the CLA treatment to have greater concentrations of P4 during the early luteal phase (d 6 to 8 of the cycle; $P=0.08$ ) from blood samples collected 3 times a week.

Results are presented as means and standard error $( \pm$ SEM $)$. For all analyses, statistical significance was declared at $P<0.05$ and a tendency at $P$ between 0.05 and 0.1. Plasma metabolites and hormones were evaluated in 3 different time periods: (1) prepartum period (wk 3 and wk 1 before calving); (2) early PP period (the day of calving, and wk 1,2, and 3 after calving), and (3) late PP period (wk 5 and the day of the fixedtime AI). Metabolites and hormones were evaluated by ANOVA for repeated measures except for wk 5 and for the day of AI, which were analyzed by one-way ANOVA. The main effects tested were diet, time, and their interactions. If differences were significant, the Dunnett test and the Tukey test were used for posthoc comparison. The time to first PP ovulation was analyzed with Kaplan-Meyer survival analysis. Cows that did not ovulate by d 50 were censored. Percentage of cows conceiving from the fixed time AI was analyzed by chi-square. For milk $\mathrm{P} 4$ concentrations after the synchronization protocol the area under the curve ( $\mathrm{P} 4$ area under the curve; P4AUC) was calculated with the trapezoid model. Statistical analysis was performed with Statistica 10 (Dell Software, Round Rock, TX) software.

\section{RESULTS}

During the experimental period, 2 animals were diagnosed with mastitis determined by the California mastitis test: Mastitest (at least one quarter gave a positive result). Those 2 cows were excluded from the final evaluation. Therefore, data of 19 (CLA1), 19 (CLA2), and 20 (control) cows were assessed.

\section{Plasma Metabolites and Hormones}

Plasma glucose concentrations decreased after calving in all 3 treatment groups $(P=0.001$ comparing day of calving vs. first week PP) with no significant differences among treatment groups either prepartum or PP (Figure 3). Plasma insulin did not differ between groups prepartum. Insulin decreased in all 3 groups after calving (comparing day of calving vs. first week PP), started to increase in the second week PP in all groups, and reached higher concentrations during the late PP period (at wk $5 \mathrm{PP}$ ) in both CLA-supplemented groups compared with the control group $(P=0.07$; Figure 3$)$.

Plasma IGF-I concentrations decreased markedly after calving in all treatment groups to less than $50 \%$ of prepartum levels at wk $1 \mathrm{PP}$. Over the next several weeks, plasma IGF-I concentrations increased earlier in both CLA-supplemented groups, reaching significantly higher values at wk 5 after calving $(P=0.12$ for CLA1 and $P=0.01$ for CLA2) and on the day of AI $(P=$ 0.02 for CLA1 and $P=0.002$ for CLA2 respectively; Figure 3).

Prepartum plasma leptin levels were not different among groups (Figure 3). Leptin concentrations decreased in all groups after calving, but tended to be higher $(P=0.06)$ throughout the early $\mathrm{PP}$ period in the cows that received CLA supplementation compared with the control group. No significant differences were observed between the 2 CLA-supplemented groups.

\section{Liver GHR1A and IGF-I mRNA Levels}

Liver GHR1A mRNA levels decreased from the initial prepartum sample to wk $1 \mathrm{PP}$ and then made some recovery by wk 5 . No effect of CLA treatment was observed. Hepatic IGF-I mRNA expression followed a similar pattern as for GHR and did not differ between groups (Figure 4).

\section{Reproductive Data}

Reproductive parameters are summarized in Table 2. Across groups, almost all cows had ovulated (16/20 in the control group; 18/19 for CLA1 and 19/19 in the CLA2 group) by d $49 \mathrm{PP}$ at the beginning of the synchronization protocol. At the same time, no difference was observed in days to first PP ovulation between groups. Percentage of cows conceiving from the fixed-time AI was higher in both CLA-treated groups 
a)

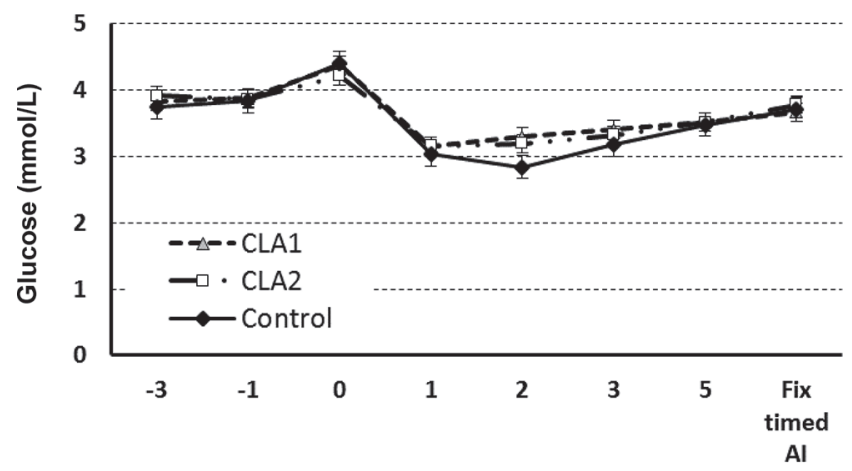

b)

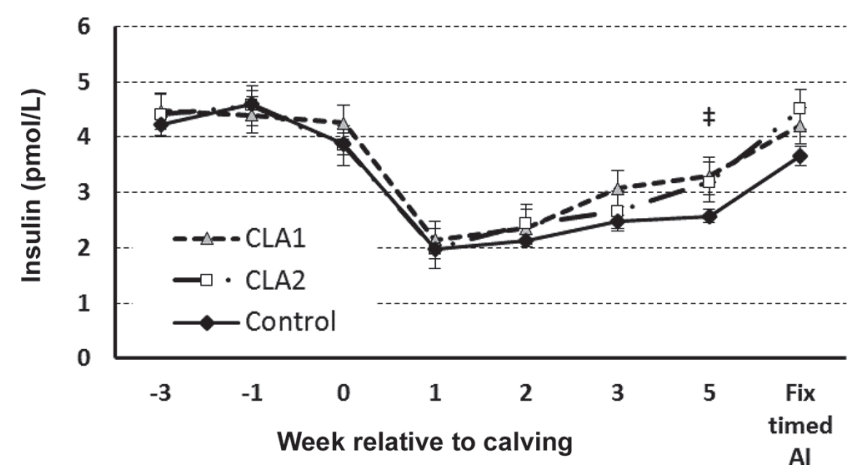

c)

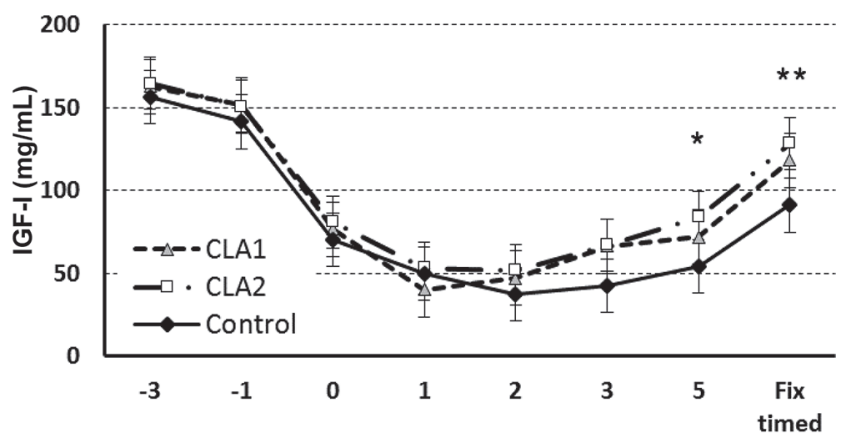

Al

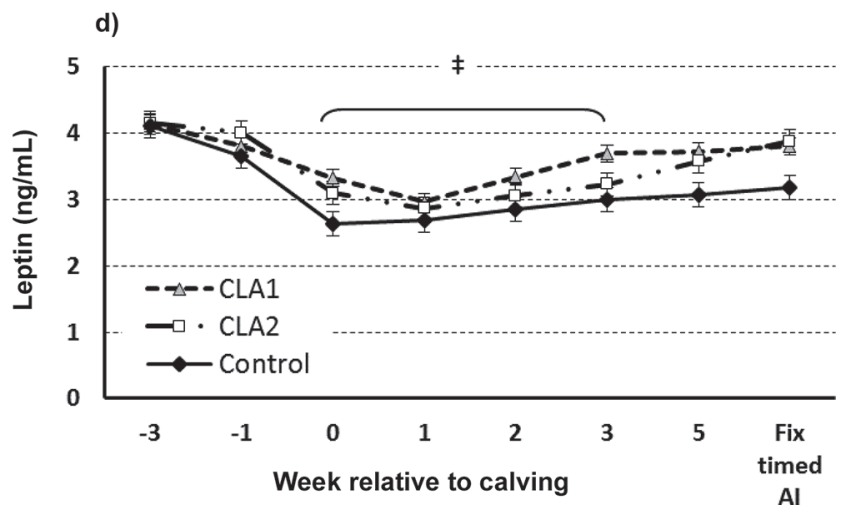

Figure 3. Plasma glucose, insulin, IGF-I, and leptin profiles of cows supplemented with CLA pre- and postpartum (CLA1), postpartum (CLA2), and nonsupplemented (control). Significant differences between groups within day are denoted as $\ddagger P<0.1 ; * P<0.05 ; * * P<0.01$. Error bars indicate SEM.

(CLA1: 47.3\%, CLA2: 57.8\%, control 40\%); meanwhile, this difference was statistically not significant $(P=$ $0.5)$. The number of $\mathrm{AI} /$ conception did not differ either. However, during lactation, cows supplemented with CLA conceived significantly earlier $(P<0.04)$ than nonsupplemented cows (Table 2). Survival analysis of the days PP to conception for all groups demonstrated that cows supplemented with CLA averaged 13 fewer days from calving to pregnancy $(P=0.02$ for CLA1 and $P=0.03$ for CLA2 vs. control, respectively; Figure $5)$. The CLA-treated cows had an earlier postovulatory rise in milk $\mathrm{P} 4$ concentrations after synchronized ovulation than the control group, and the P4AUC between $\mathrm{d}$ 2 and 5 was higher in both CLA-supplemented groups compared with the control cows $(P=0.02$, Figure 6).

Based on the combination of PSPB data, P4 profile and rectal ultrasound examinations, late embryonic mortality between d 16 and 35 occurred in 2 cows in CLA1, 1 in CLA2, and 2 cases in control.

\section{DISCUSSION}

In this study we observed that the supplementation of dairy cows with a mixture of lipid-encapsulated cis-9,trans-11 CLA and trans-10,cis-12 CLA either prepartum and PP (CLA1 group) or only PP (CLA2 group) resulted in a more rapid postovulatory $\mathrm{P} 4$ rise after the modified Pre-Synch protocol and fewer days from calving to pregnancy. We speculate that higher plasma P4 concentrations provided a more optimum environment for embryo development and resulted in earlier conception rates during lactation.

Proportion of cows conceiving from timed AI was higher in both CLA-treated groups; however, this difference was statistically not significant. A higher sample size and a longitudinal cohort study design would probably be more adequate to assess this parameter. On the other hand, survival analysis of the time from calving to conception showed statistical significance. In contrast, the study of Hutchinson at al. (2012) including a higher number of animals $(\mathrm{n}=203$ supplemented vs. $\mathrm{n}=206$ control) in a pasture-based system could not demonstrate a significant difference in the interval from calving to conception, overall embryo mortality, and pregnancy rate. It is important to stress that their experiment was performed under pasture-based conditions and not with high-yielding cows; therefore, NEB was probably less determinant. 
The intensive milk sampling following synchronized ovulation allowed to follow up steroidogenesis during the early luteal phase. Consistent evidence has indicated that improvement of P4 secretion of CL after ovulation has positive effects later on the maternal recognition of pregnancy (Meyer et al., 1995; Mann et al., 2006; Miyamoto et al., 2010). We found a greater $\mathrm{P} 4 \mathrm{AUC}$ in CLA-supplemented groups between d 2 and 5 following AI. This finding is in agreement with Castañeda-Gutiérrez et al. (2007) where CLA isomers supplementation was started on d 20 PP. They observed increased postovulatory $\mathrm{P} 4$ rise between $\mathrm{d} 6$ and 8 following ovulation in cows supplemented with 2 different CLA preparations. Furthermore, higher P4AUC and higher plasma IGF-I were measured when more trans-10,cis-12 CLA was administered. The beneficial effect of CLA was suggested to be attributed to elevated plasma IGF-I, which promotes follicular and luteal cell proliferation, induced P4 synthesis (Perks et

a)

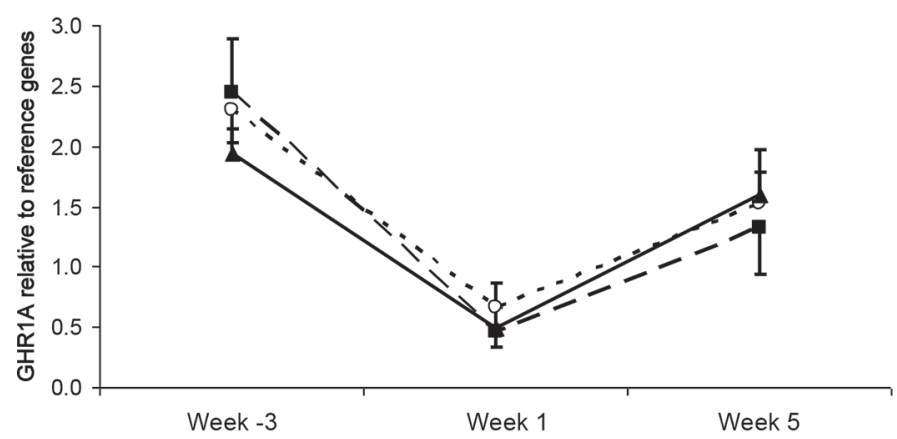

b)

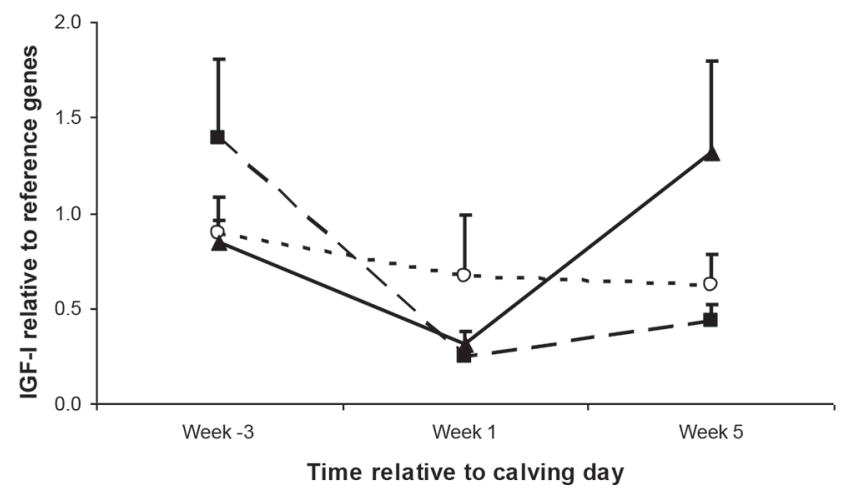

Figure 4. Expression of growth hormone receptor 1A (GHR1A), and $I G F-I$ mRNA in hepatic tissue at $3 \mathrm{wk}$ before parturition, $1 \mathrm{wk}$ postpartum, and $5 \mathrm{wk}$ postpartum in groups of CLA-supplemented and control cows. $\square-$ - CLA1; $\bigcirc \cdots$ CLA $2 ; \boldsymbol{\Delta}-$ control. CLA1 = CLA supplementation from $3 \mathrm{wk}$ before expected calving; CLA2 = CLA supplementation from calving; control = without CLA supplementation. Error bars indicate SEM. al., 1999), and increased LH binding by bovine thecal cells (Stewart et al., 1995). The mechanism by which trans-10,cis-12 CLA increased circulating IGF-I levels remained unclear, but seemed to be independent of energy balance, and perhaps mediated by subtle changes in hepatic sensitivity to insulin (Castañeda-Gutiérrez et al., 2007). Besides in vivo experiments, the direct effect of CLA was also tested in lutein cell cultures (May et al., 2011). These in vitro studies could not prove any direct effect of CLA on P4 production of lutein cells, while suggested that suppressing $\mathrm{PGF}_{2 \alpha}$ synthesis in luteal cells via attenuation of $C O X-2$ gene expression may end in better reproductive performance. Therefore, CLA-induced elevated IGF-I production of liver seems to be responsible for higher $\mathrm{P} 4$ levels rather than direct effect of CLA on ovaries.

The main source of IGF-I is the liver and regulated by the somatotropic axis. During normal energy status, GH binds to its receptors in the liver, mainly through GHR1A stimulating secretion of IGF-I (Lucy, 2000; Renaville et al., 2002). Early after calving, high-yielding dairy cows enter NEB and the GH-hepatic GHR1AIGF-I axis becomes uncoupled through the downregulation of GHR1A (GH resistance; Kobayashi et al., 1999; Radcliff et al., 2003). The IGF-I and GH are regulated in a negative feedback loop, so that, as IGF-I decreases, the negative feedback on GH is reduced, resulting in an increase in plasma GH (Lucy, 2000; Renaville et al., 2002). In the current study, plasma IGF-I concentrations decreased immediately after calving during the first week PP to $<50 \%$ of prepartal levels. During the next several weeks, we observed higher plasma IGFI levels in both CLA-supplemented groups compared with controls during the late PP period. This pattern and response to CLA supplementation are in agreement with Castañeda-Gutiérrez et al. (2007).

Based on these results, the next question was whether and how CLA supplementation modulates the somatotropic axis. In this context, we detected similar GHR1A mRNA patterns related to time PP as reported previously (Kobayashi et al., 1999; Radcliff et al., 2003) as liver IGF-I production becomes uncoupled. Our results demonstrate that CLA supplementation did not affect $\mathrm{GH}$ receptor gene expression. Another candidate to explain the uncoupling mechanism for hepatic IGF-I production is decreased insulin availability PP known to play an important role in the control of hepatic IGF-I production. Elevated insulin levels result in an increase in liver $\mathrm{GH}$ receptor number and increased plasma IGF-I concentrations (Butler et al., 2003; Hammon et al., 2012). We measured plasma insulin concentrations, but differences among groups were not significant. Although we could not detect differences in GHR1A mRNA or in IGF-I mRNA expression in liver samples 


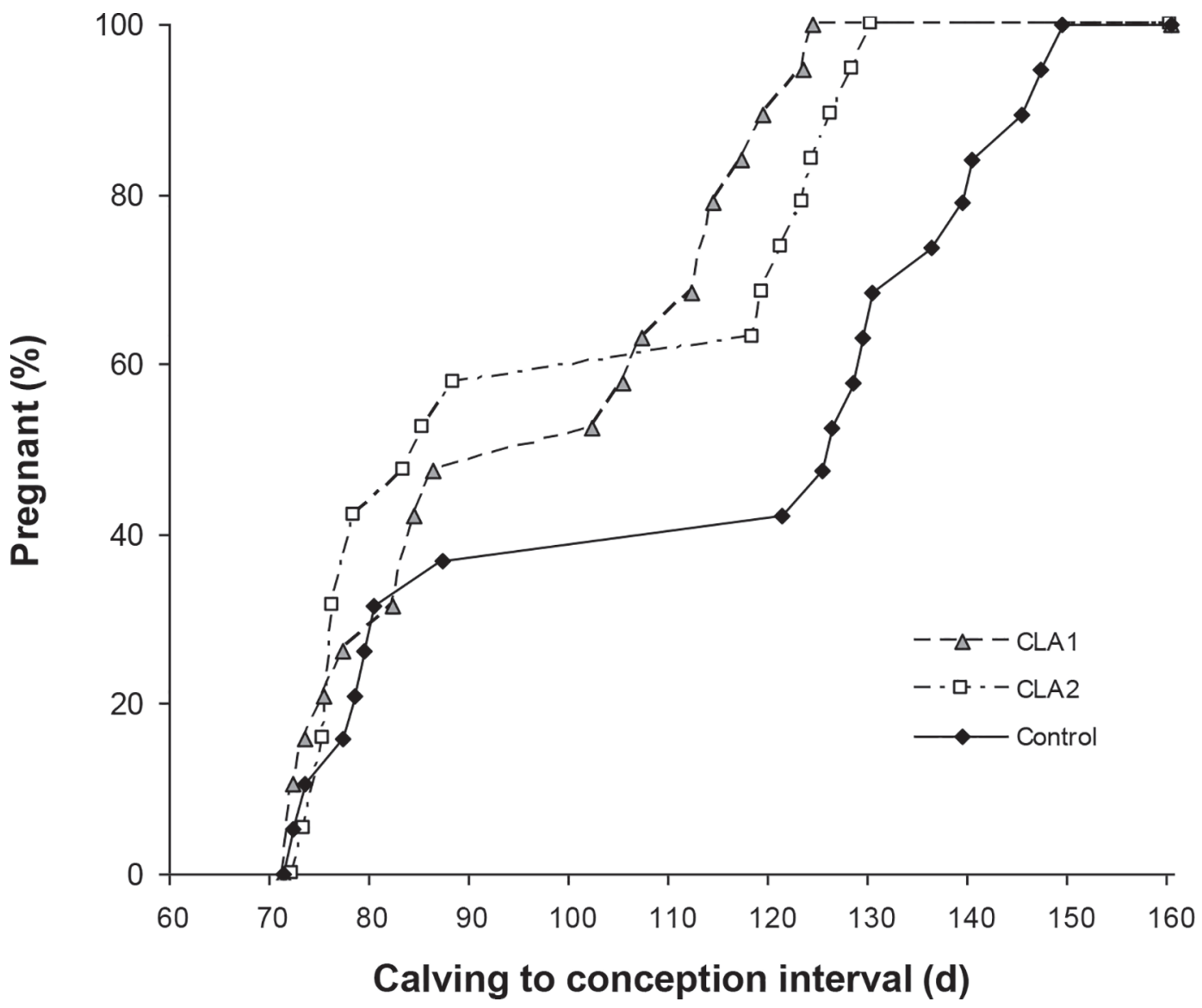

Figure 5. Survival analysis of days from calving to conception in cows supplemented with CLA compared with control. CLA1 = cows supplemented from $3 \mathrm{wk}$ before the expected day of parturition until $7 \mathrm{~d}$ following timed AI; CLA2 = cows supplemented from parturition until $7 \mathrm{~d}$ following timed AI. Kaplan-Meier survival analysis: $P=0.04$. Comparison between groups for days to conception (Gehan's Wilcoxon test): CLA1 versus control, $P=0.02$; CLA2 versus control, $P=0.03$; CLA1 versus CLA2, $P=0.64$. All animals became pregnant during the experimental period.

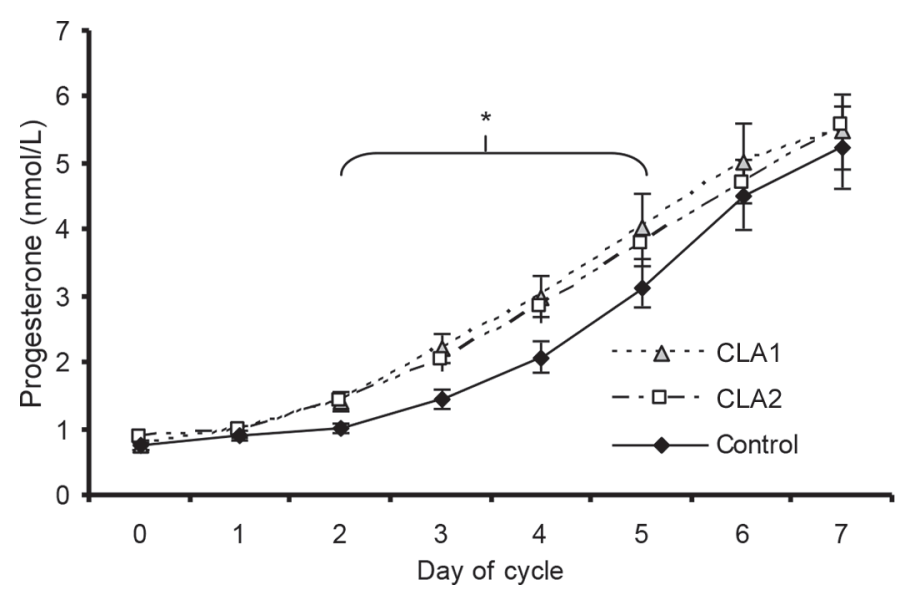

Figure 6. Milk progesterone concentrations (means \pm SEM) following ovulation synchronization in CLA-supplemented cows compared with controls. CLA $1=$ cows supplemented from 3 wk before the expected day of parturition until $7 \mathrm{~d}$ following timed AI; CLA2 = cows supplemented from parturition until $7 \mathrm{~d}$ following timed AI. ${ }^{*} P$-value for progesterone area under the curve for d 2 to $5=0.02$. Error bars indicate SEM. at $30 \mathrm{~d}$ of lactation, plasma IGF-I concentrations were greater in the CLA-supplemented groups for wk 5 and on the day of AI. This discrepancy may be ascribed to the fact that we collected liver samples only at the first and fifth week PP. It is also possible that elevated IGFI production is regulated at the posttranscriptional cellular level.

Insulin and IGF-I are among the most important metabolic hormone signals modulating reproductive performance [e.g., earlier resumption of ovarian cyclicity, more intensive follicular development, and improved fertility (Butler and Smith, 1989; Chun et al., 1994; Lucy, 2000; Butler, 2001; Comin et al., 2002; Butler, 2003; Taylor et al., 2004; Crowe, 2008)]. Increased IGFI plays a critical role during maturation of $\mathrm{PP}$ dominant follicles and improves ovarian steroidogenesis (Butler et al., 2004). Expression of mRNA encoding IGF-I, IGFII, and the type 1 IGF receptor has also been detected in the ruminant CL, which further supports the key 
function of the IGF hormone family in the regulation of luteal function (Webb et al., 2002). Therefore, we hypothesize that higher IGF-I levels induced postovulatory $\mathrm{P} 4$ rise, which contributed to better fertility of the CLA-treated groups.

Hutchinson et al. (2011) found more balanced body conditions and lower nonesterified fatty acid levels in CLA-treated cows. In the present study, plasma leptin levels were maintained higher in the early PP period in CLA-supplemented animals. Plasma leptin level is closely related to BCS, and together with nonesterified fatty acids are important parameters connecting fat metabolism and reproduction. The metabolic findings of the same experiment are detailed in a separate paper (Galamb et al., 2016). We found reduced fat mobilization in CLA-supplemented animals, which probably contributed to better reproductive performance.

\section{CONCLUSIONS}

We have demonstrated that dietary supplementation with CLA isomers to dairy cows resulted in a higher postovulatory $\mathrm{P} 4$ rise and higher fertility as reflected by fewer days from calving to conception. Higher plasma IGF-I and leptin level can be important metabolic signals for follicle development and improved CL function; however, we did not find any effects of CLA isomers on hepatic GHR1A expression. Further investigations are necessary to define the exact mode of action of CLA as well as to understand its role in the regulation of the somatotropic axis regulating liver IGF-I secretion.

\section{ACKNOWLEDGMENTS}

We thank Péter Elek (DELACON Biotechnika Ltd., Cházár A., Vác, Hungary) for his participation in the compilation of TMR recipes, to Alice Vona Nagy (University of Veterinary Medicine, István, Budapest, Hungary) for her technical assistance in hormone measurements, to Judit Varga (Georgikon Faculty, University of Pannonia, Keszthely, Hungary) for her enthusiastic contribution to both field work and laboratory analysis of milk samples. The study was financially supported by BASF SE (Lampertheim, Germany).

\section{REFERENCES}

Balogh, O. G., H. Febel, G. Huszenicza, M. Kulcsar, Z. Abonyi-Toth, T. Endrodi, and G. Gabor. 2012. Seasonal fertility differences in synchronised dairy cows: Ultrasonic, metabolic and endocrine findings. Acta Vet. Hung. 60:131-143.

Beam, S. W., and W. R. Butler. 1999. Effects of energy balance on follicular development and first ovulation in postpartum dairy cows. J. Reprod. Fertil. Suppl. 54:411-424.
Bernal-Santos, G., J. W. Perfield, D. M. Barbano, D. E. Bauman, and T. R. Overton. 2003. Production responses of dairy cows to dietary supplementation with conjugated linoleic acid (CLA) during the transition period and early lactation. J. Dairy Sci. 86:3218-3228.

Butler, S. T., A. L. Marr, S. H. Pelton, R. P. Radcliff, M. C. Lucy, and W. R. Butler. 2003. Insulin restores GH responsiveness during lactation-induced negative energy balance in dairy cattle: Effects on expression of IGF-I and GH receptor 1A. J. Endocrinol. 176:205-217.

Butler, S. T., S. H. Pelton, and W. R. Butler. 2004. Insulin increases 17b-estradiol production by the dominant follicle of the first postpartum follicle wave in dairy cows. Reproduction 127:537-545.

Butler, S. T., S. H. Pelton, and W. R. Butler. 2006. Energy balance, metabolic status, and the first postpartum ovarian follicle wave in cows administered propylene glycol. J. Dairy Sci. 89:2938-2951.

Butler, W. R. 2000. Nutritional interactions with reproductive performance in dairy cattle. Anim. Reprod. Sci. 60-61:449-457.

Butler, W. R. 2001. Nutritional effects on resumption of ovarian cyclicity and conception rate in postpartum dairy cows. Anim. Sci. $26: 133-145$.

Butler, W. R. 2003. Energy balance relationships with follicular development, ovulation and fertility in postpartum dairy cows. Livest. Prod. Sci. 83:211-218.

Butler, W. R., and R. D. Smith. 1989. Interrelationships between energy balance and postpartum reproductive function in dairy cattle. J. Dairy Sci. 72:767-783.

Castañeda-Gutiérrez, E., B. C. Benefield, M. J. de Veth, N. R. Santos, R. O. Gilbert, W. R. Butler, and D. E. Bauman. 2007. Evaluation of the mechanism of action of conjugated linoleic acid isomers on reproduction in dairy cows. J. Dairy Sci. 90:4253-4264.

Castañeda-Gutiérrez, E., T. R. Overton, W. R. Butler, and D. E. Bauman. 2005. Dietary supplements of two doses of calcium salts of conjugated linoleic acid during the transition period and early lactation. J. Dairy Sci. 88:1078-1089.

Chagas, L. M., J. J. Bass, D. Blache, C. R. Burke, J. K. Kay, D. R. Lindsay, M. C. Lucy, G. B. Martin, S. Meier, F. M. Rhodes, J. R. Roche, W. W. Thatcher, and R. Webb. 2007. Invited Review: New perspectives on the roles of nutrition and metabolic priorities in the subfertility of high-producing dairy cows. J. Dairy Sci. 90:4022-4032.

Chun, S. Y., H. Billig, J. L. Tilly, I. Furuta, A. Tsafriri, and A. J. Hsueh. 1994. Gonadotropin suppression of apoptosis in cultured preovulatory follicles: Mediatory role of endogenous insulin-like growth factor I. Endocrinology 135:1845-1853.

Comin, A., D. Gerin, A. Cappa, V. Marchi, R. Renaville, M. Motta, U. Fazzini, and A. Prandi. 2002. The effect of an acute energy deficit on the hormone profile of dominant follicles in dairy cows. Theriogenology 58:899-910.

Crowe, M. A. 2008. Resumption of ovarian cyclicity in post-partum beef and dairy cows. Reprod. Domest. Anim. 43:20-28.

de Veth, M. J., D. E. Bauman, W. Koch, G. E. Mann, A. M. Pfeiffer, and W. R. Butler. 2009. Efficacy of Conjugated Linoleic Acid for improving reproduction: A multi-study analysis in early-lactation dairy cows. J. Dairy Sci. 92:2662-2669.

Galamb, E., V. Faigl, M. Keresztes, Z. Csillik, A. Tröscher, P. Elek, M. Kulcsár, G. Huszenicza, H. Fébel, and F. Husvéth. 2016. Effect of pre- and postpartum supplementation with lipid-encapsulated conjugated linoleic acid on milk-yield and metabolic status in multiparous high-producing dairy cows. J. Anim. Physiol. Anim. Nutr. (Berl.) https://doi.org/10.1111/jpn.12544.

Hammon, H. M., U. Kautzsch, C. Weber, B. Kuhla, M. Röntgen, and R. M. Bruckmaier. 2012. Insulin action on hepatic gene expression in dairy cows with different fat mobilization during early lactation. J. Dairy Sci. 95(Suppl. 2):319. (Abstr.)

Hammon, H. M., G. Stürmer, F. Schneider, A. Tuchscherer, H. Blum, T. Engelhard, A. Genzel, R. Staufenbiel, and W. Kanitz. 2009. Performance and metabolic and endocrine changes with emphasis on glucose metabolism in high-yielding dairy cows with high and low fat content in liver after calving. J. Dairy Sci. 92:1554-1566.

Hutchinson, I., M. J. de Veth, C. Stanton, R. J. Dewhurst, P. Lonergan, A. C. Evans, and S. T. Butler. 2011. Effects of lipid-encapsu- 
lated conjugated linoleic acid supplementation on milk production, bioenergetic status and indicators of reproductive performance in lactating dairy cows. J. Dairy Res. 78:308-317.

Hutchinson, I. A., A. A. Hennessy, R. J. Dewhurst, A. C. O. Evans, P. Lonergan, and S. T. Butler. 2012. The effect of strategic supplementation with trans-10, cis-12 conjugated linoleic acid on the milk production, estrous cycle characteristics, and reproductive performance of lactating dairy cattle. J. Dairy Sci. 95:2442-2451.

Inskeep, E. K. 2004. Preovulatory, postovulatory, and postmaternal recognition effects of concentrations of progesterone on embryonic survival in the cow. J. Anim. Sci. 82(E-Suppl.):E24-E39.

Jorritsma, R., H. Jorritsma, Y. H. Schukken, and G. H. Wentink. 2000. Relationships between fatty liver and fertility and some periparturient diseases in commercial Dutch dairy herds. Theriogenology 54:1065-1074.

Kendall, P. E., T. L. Auchtung, K. S. Swanson, R. P. Radcliff, M. C. Lucy, J. K. Drackley, and G. E. Dahl. 2003. Effect of photoperiod on hepatic growth hormone receptor $1 \mathrm{~A}$ expression in steer calves. J. Anim. Sci. 81:1440-1446.

Kerestes, M., V. Faigl, M. Kulcsár, O. Balogh, J. Földi, H. Fébel, Y Chilliard, and G. Huszenicza. 2009. Periparturient insulin secretion and whole-body insulin responsiveness in dairy cows showing various forms of ketone pattern with or without puerperal metritis. Domest. Anim. Endocrinol. 37:250-261.

Kobayashi, Y., C. K. Boyd, C. J. Bracken, W. R. Lamberson, D. H. Keisler, and M. C. Lucy. 1999. Reduced growth hormone receptor (GHR) messenger ribonucleic acid in liver of periparturient cattle is caused by a specific down-regulation of GHR 1A that is associated with decreased insulin-like growth factor-I. Endocrinology 140:3947-3954.

Lucy, M. C. 2000. Regulation of ovarian follicular function by somatotropin and insulin-like growth factors in cattle. J. Dairy Sci. 83:1635-1647.

Lucy, M. C. 2001. Reproductive loss in high-producing dairy cattle: Where it will end? J. Dairy Sci. 84:1277-1293.

Mann, G. E., M. D. Fray, and G. E. Lamming. 2006. Effects of time of progesterone supplementation on embryo development and interferon-tau production in the cow. Vet. J. 171:500-503.

Mattos, R., C. R. Staples, and W. W. Thatcher. 2000. Effects of dietary fatty acids on reproduction in ruminants. Rev. Reprod. $5: 38-45$.

May, K. C., G. Bobe, C. J. Mueller, and M. J. Cannon. 2011. Conjugated linoleic acid decreases prostaglandin synthesis in bovine luteal cells in vitro. Mol. Reprod. Dev. 78:328-336.

Meyer, M. D., P. J. Hansen, W. W. Thatcher, M. Drost, L. Badinga, R. M. Roberts, J. Li, T. L. Ott, and F. W. Bazer. 1995. Extension of corpus luteum lifespan and reduction of uterine secretion of prostaglandin $\mathrm{F} 2 \alpha$ of cows in response to a recombinant interferontau. J. Dairy Sci. 78:1921-1931.

Miyamoto, A., K. Shirasuna, T. Shimizu, H. Bollwein, and D. Schams. 2010. Regulation of corpus luteum development and maintenance: Specific roles of angiogenesis and action of prostaglandin F2. Pages 289-304 in Reproduction in Domestic Ruminants VII. M. C. Lucy, J. L. Pate, M. F. Smith, and T. E. Spencer, ed. Nottingham University Press.
Moreira, F., C. Orlandi, C. A. Risco, R. Mattos, F. Lopes, and W. W. Thatcher. 2001. Effects of presynchronization and bovine somatotropin on pregnancy rates to a timed artificial insemination protocol in lactating dairy cows. J. Dairy Sci. 84:1646-1659.

National Research Council. 2001. Nutrient Requirements of Dairy Cattle. 7th rev. ed. National Academy of Sciences, Washington, DC.

O'Callaghan, D., and M. P. Boland. 1999. Nutritional effects on ovulation, embryo development and the establishment of pregnancy in ruminants. Anim. Sci. 68:299-314.

Perks, C. M., A. R. Peters, and D. C. Wathes. 1999. Follicular and luteal expression of insulin-like growth factors I and II and the type-1 IGF receptors in the bovine ovary. J. Reprod. Fertil. 116:157-165.

Pfaffl, M. W., T. M. Georgieva, I. P. Georgiev, E. Ontsouka, M. Hageleit, and J. W. Blum. 2002. Real-time RT-PCR quantification of insulin-like growth factor (IGF)-1, IGF-1 receptor, IGF-2, IGF-2 receptor, insulin receptor, growth hormone receptor, IGFbinding proteins 1, 2 and 3 in the bovine species. Domest. Anim. Endocrinol. 22:91-102.

Radcliff, R. P., B. L. McCormack, B. A. Crooker, and M. C. Lucy. 2003. Plasma hormones and expression of growth hormone receptor and insulin-like growth factor-I mRNA in hepatic tissue of periparturient dairy cows. J. Dairy Sci. 86:3920-3926.

Renaville, R., M. Hammadi, and D. Portetelle. 2002. Role of the somatotropic axis in the mammalian metabolism. Domest. Anim. Endocrinol. 23:351-360.

Robinson, R. S., P. G. Pushpakumara, Z. Cheng, A. R. Peters, D. R. Abayasekara, and D. C. Wathes. 2002. Effects of dietary polyunsaturated fatty acids on ovarian and uterine function in lactating dairy cows. Reproduction 124:119-131.

Rukkwamsuk, T., I. Wensing, and T. A. M. Kruip. 1999. Relationship between triacylglycerol concentration in the liver and first ovulation in postpartum dairy cows. Theriogenology 51:1133-1142.

Stewart, R. E., L. J. Spicer, T. D. Hamilton, and B. E. Keefer. 1995. Effects of insulin-like growth factor I and insulin on proliferation and on basal and luteinizing hormone-induced steroidogenesis of bovine thecal cells: Involvement of glucose and receptors for insulin-like growth factor I and luteinizing hormone. J. Anim. Sci 73:3719-3731

Taylor, V. J., Z. Cheng, P. G. Pushpakumara, D. E. Beever, and D. C. Wathes. 2004. Relationships between the plasma concentrations of insulin-like growth factor-I in dairy cows and their fertility and milk yield. Vet. Rec. 155:583-588.

Webb, R., B. K. Campbell, H. A. Garverick, J. G. Gong, C. G. Gutierrez, and D. G. Armstrong. 1999. Molecular mechanisms regulating follicular recruitment and selection. J. Reprod. Fertil. Suppl. 54:33-48.

Webb, R., K. J. Woad, and D. G. Armstrong. 2002. Corpus luteum (CL) function: Local control mechanisms. Domest. Anim. Endocrinol. 23:277-285.

Wiltbank, M., H. Lopez, R. Sartori, S. Sangsritavory, and A. Gümen. 2006. Changes in reproductive physiology of lactating dairy cows due to elevated steroid metabolism. Theriogenology 65:17-29. 